\title{
DÜBLIN
}

Technological University Dublin

ARROW@TU Dublin

\section{Biopharmaceutical Revolution in Saudi Arabia: Progress and Development}

\author{
Rihana Alzahran \\ Technological University Dublin, rihana.alzahran@tudublin.ie \\ Elaine Harris \\ Technological University Dublin, elaine.harris@tudublin.ie
}

Follow this and additional works at: https://arrow.tudublin.ie/scschcpsart

Part of the Pharmacy and Pharmaceutical Sciences Commons

\section{Recommended Citation}

Alzahran, R. \& Harris, E. (2020). Biopharmaceutical Revolution in Saudi Arabia: Progress and Development. Journal of Pharmaceutical Innovation, vol. 16, pg. 110-123. https://doi.org/10.1007/ s12247-020-09429-1

This Article is brought to you for free and open access by the School of Chemical and Pharmaceutical Sciences at ARROW@TU Dublin. It has been accepted for inclusion in Articles by an authorized administrator of ARROW@TU Dublin. For more information, please contact arrow.admin@tudublin.ie, aisling.coyne@tudublin.ie, gerard.connolly@tudublin.ie.

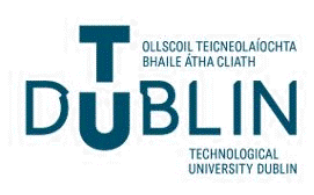


See discussions, stats, and author profiles for this publication at: https://www.researchgate.net/publication/338714032

\section{Biopharmaceutical Revolution in Saudi Arabia: Progress and Development}

Article in Journal of Pharmaceutical Innovation · January 2020

DOI: 10.1007/12247-020-09429-1

2 authors, including:

(E)

Elaine Harris

TU Dublin

29 PUBLICATIONS 29 CITATIONS

SEE PROFILE

Some of the authors of this publication are also working on these related projects:

Sciect Science and Knowledge Management View project

Innovative Theraputics Regulatory Pathways View project 


\title{
Biopharmaceutical Revolution in Saudi Arabia: Progress and Development
}

\author{
Rihana Alzahrani ${ }^{1}$ (D) Elaine Harris ${ }^{2}$ \\ (C) Springer Science+Business Media, LLC, part of Springer Nature 2020
}

\begin{abstract}
Purpose This paper aimed to analyze the situation of the biopharmaceutical industry in Saudi Arabia to improve the situation in a way that achieves high levels of development similar to those in Europe, the United States of America (USA), and Japan.

Methods To achieve the objective of the study, the authors surveyed 18 out of 21 Saudi pharmaceutical companies that have received licensing for manufacturing from the Saudi Food and Drug Authority (SFDA) to diagnose the situation of manufacturing in relation to biopharmaceuticals. An interview with SFDA officials was carried out as a supplement to the survey.

Results Findings revealed a serious lack of manufacturing of biopharmaceuticals in Saudi Arabia. In addition, knowledge of biopharmaceutical practice in upstream and downstream bioprocessing is poor. The analysis of interviews revealed some progress in biopharmaceuticals in Saudi Arabia, namely, applications to manufacture insulin and vaccines.

Conclusion On the basis of the findings, recommendations were made to develop the situation of biopharmaceutics in Saudi Arabia.
\end{abstract}

Keywords Biopharmaceutics · Development $\cdot$ Saudi Arabia $\cdot$ Companies $\cdot$ SDFA

\section{Introduction}

Biopharmaceuticals represent one of the most impressive developments in modern science [1]. In general, a pharmaceutical is a product manufactured using live organisms and has an active ingredient, which is biological in nature. Specifically, biopharmaceuticals are composed of living organisms manufactured via biotechnology methods [2]. Biopharmaceuticals are defined by The European Pharmacopeia as "target gene expression products that are obtained through extraction and purification after gene modification in which the target gene is introduced into suitable micro-organisms or cells via plasmids or viral vectors, thereby promoting the expression and translation (to form corresponding proteins) of DNA" [3].

Rihana Alzahrani

rihanaalzaharni@gmail.com

Elaine Harris

elaine.harris@dit.ie

1 Bisha University, Bisha, Saudi Arabia

2 School of Chemical and Pharmaceutical Sciences, Dublin Institute of Technology, Kevin Street, Portobello, Dublin 2 D08 X622, Ireland

\section{Development in Biopharmaceutics}

Biopharmaceuticals represent one of the most important developments in modern science [1]. The novelty in this industry is the production of drugs via biotechnology, which is considered innovative among other related industries. The previous study classified biopharmaceuticals into first- and secondgeneration biopharmaceuticals. The former can be classified further into human growth hormone, G-CSF, erythropoietin, and some human proteins manufactured using genetic recombination technology. The latter is created using genome information or via gene functional analysis [4].

First-generation biopharmaceuticals underwent great development in which the biopharmaceutical market scale in 2002 was approximately 1 trillion yen (with a 7 trillion-yen market in relation to prescription drugs). Second-generation pharmaceuticals, such as monoclonal antibodies, are currently being developed. Overall, the proportion of biopharmaceuticals in relation to prescription drugs is slowly growing [4]. In 2005, the market for biopharmaceuticals increased at a worldwide level with yearly growth spurts of 15-33\%, and their sales exceeded $\$ 55$ billion.

According to Humulin ${ }^{\circledR}$, recombinant human (rh) insulin is the first biotechnology drug that has been manufactured by Genentech, alongside Eli Lilly, and was passed by the US 
Food and Drug Administration (FDA) in 1982. Humulin ${ }^{\circledR}$ can be equated with the emergence of the biopharmaceutical industry. Since its arrival, more than 100 biopharmaceuticals have been granted permission for general use by people within the EU and the USA [5].

In 2008, more than 120 biopharmaceuticals were present in the global market, while more than 400 new biopharmaceuticals were developed globally [2]. A new medicine requires more than 10 years to undergo the whole research and development $(R \& D)$ process. This process begins with the stage where the compound is identified and ends when it is approved by the US FDA. On average, the amount of finances required to develop a new medicine is approximately $\$ 2.6$ billion [6]. This estimate includes the expense caused by failures, because several compounds that are examined are not granted FDA approval. The expense involved in such development has risen by more than $100 \%$ over the last decade, indicating the increasing complexity involved in the process [6].

A potential revolution in drug development strategies has come with the new knowledge generated through the human genome project and related biomedical research. Recombinant protein-based therapeutics is one of the most direct applications of this knowledge. Well-established biotechnology companies have adopted the commercial production of these proteins [7].

Upstream and downstream processing are considered basic steps in bioprocessing. Upstream processing is a part of biotechnology and is considered the first step in bioprocessing, including cell isolation and cultivation. This process is followed by cell banking and culture expansion in bioreactors, and, finally, the harvesting step. Downstream processing encompasses all process steps from cell harvest to the final purified product and has three main steps, namely, cell disruption, purification, and polishing [8].

Since September 2011, the FDA has approved approximately 135 biopharmaceuticals, such as recombinant antibodies, enzymes, polyethylene glycol-based products, cytokines, hormones, and other modifiers. These compounds are important for the treatment of several potentially fatal diseases, indicating the importance of biopharmaceuticals in the economy. The yearly return from biopharmaceuticals in the worldwide pharmaceutical industry has been steadily increasing since 2000 , providing $15.19 \%$ of entire sales in the healthcare industry during 2010 . Among the top 10 medicines with the largest global revenues in 2010, half are biopharmaceuticals, and the remaining are therapeutic antibodies. The combined return reaped from these products has amounted to US\$40.9 billion.

\section{Development of Biopharmaceutics in USA}

The USA is a pioneer in the biopharmaceutical industry. Its performance exceeds that of all other nations, accounting for a greater number of companies, higher funds in relation to $\mathrm{R} \& \mathrm{D}$, swifter regulatory permission for new products, and a better-working public market [9]. US biopharmaceutical organizations are also global pioneers in biopharmaceutical research and commercialization [10]. Furthermore, the industry is nearer to profitability than at any other stage in its history [9]. The US possesses the most sophisticated biopharmaceutical industry in R\&D and a wide array of products and market scale. Most biopharmaceuticals are licensed initially in the USA and later in other areas [3].

The biopharmaceutical field in the USA involves many companies, which are considerably larger than those of the European industry. The number of years since the companies have been established slightly differs in each area, as indicated by the enhanced market reach of US companies and their more widely dispersed development activities and customer types.

Regarding external assistance, European companies tend to receive governmental financial aid more often than US companies, because US firms tend to obtain such funding from commercial entities [9]. A much higher percentage of US firms $(80.5 \%)$ cultivates early partnerships with universities than in Europe (71.5\%). This difference may be due to the US investment in university research relating to biopharmaceutical firms, thereby ensuring that US companies have a stronger incentive to ally with universities than their European equivalents [9].

Among the 131 pharmacy fellowship programs offered in the USA, 58 are concentrated on developing competencies that aid careers in the biopharmaceutical and pharmaceutical sector. Most of the industry fellowship programs relate to academic bodies, while others are associated with companies. For example, Rutgers University in New Jersey, USA, has 13 business partners, yielding more than 70 pharmacy fellowships annually to ensure that students are well trained for a pharmaceutical industrial career [11].

\section{Development of Biopharmaceutics in China}

In China's National Twelfth Five-Year Plan, the biopharmaceutical industry was referred to as an "emerging industry of strategic importance." By encouraging a holistic "upgrade" of the industry and ensuring its competitiveness, China may achieve a large pharmaceutical industry with a robust pharmaceutical sector. This step should support the effective operation of public healthcare systems and ensure new driving forces for economic growth [3].

China's substantial biotechnology research bases, in conjunction with its skilled supply of workers and its relatively low resource costs, mean that it is an attractive prospect for biopharmaceutical firms seeking to engage in overseas outsourcing. The Chinese government has modified policies, enhanced investment, and improved the protection of intellectual property to encourage investment. The Chinese government facilitates this development via changes in policy, allowing opportunities for established biopharmaceutical 
companies. Certain business commentators anticipate that China will become the world's third largest pharmaceutical region, following the USA and Japan [12].

New, low-cost locations, including China and India, have a very small contribution to worldwide biopharmaceutical research because of their low resource costs. Although biopharmaceutical growth in these nations has been swift in recent years, its consistent size remains difficult to gauge, considering the powerful economic forces affecting agglomeration and "clustering" in biomedical research. In terms of the effect of worldwide development of biopharmaceutical R\&D on host country knowledge activity, foreign knowledge discovery along biopharmaceutical companies may complement, rather than replace, home country activities [13].

\section{Development of Biopharmaceutics in Saudi Arabia}

Biological products in the Saudi Arabia market are subject to a marketing authorization assessment. Permission for biological products can only be obtained when the relevant product satisfies the specifications. Such applications in relation to biological products are categorized based on the purpose of the application. The categories are as follows: new registration, variation, and renewal. The process begins with the validation and concludes with either approval or rejection. The pharmaceutical industry has devised several guidelines for these processes [14].

Saudi Arabia is the most significant pharmaceutical market in the Middle East region and has a swiftly increasing population. Its gross domestic product (GDP) is included in the top 30 worldwide. Thus, it is an encouraging market for biopharmaceutical firms. Its market was expected to rise to almost US\$5B in 2016. The healthcare system in the country is decentralized, while decisions regarding reimbursement are executed by specific government sectors (ministries). Recent changes in the healthcare sector have sought to cultivate a cost-sensitive environment. Most pharmacy departments in specialist hospitals within the three main cities perform pharmacoeconomic reviews. However, their effectiveness is less than that of the clinical review.

At present, the Saudi FDA is the regulatory body dedicated for pricing and reimbursement. Although it is a complicated market, it is relatively large and developing. Thus, investment may increase the profile of the country and offer attractive opportunities for manufacturers. Considering the sizeable population and readiness to pay for such products, Saudi Arabia is an extremely attractive market that must be investigated by pharmaceutical companies [15].

The Ministry of Health is traditionally the main pharmaceutical regulatory body in Saudi Arabia that registers all pharmaceutical firms operating in the country. Since the SFDA was established in March 2003, it ultimately assumed this role in July 2009 pursuant to Royal Decree No. M/6 of 25/
1/1428 H (13/2/2007 G). It was tasked with licensing pharmaceutical products and manufacturing facilities [16].

Saudi Arabia accounts for approximately $65 \%$ of all pharmaceutical purchases in the Gulf Cooperation Council region, while $82 \%$ of the kingdom's requirement is satisfied via imports, thereby signifying a major growth opportunity for domestic pharmaceutical organizations. Nonetheless, poor investments in research and development due to lack of sufficiently skilled personnel and dearth of technical knowledge and insufficient infrastructure have led to the underdevelopment of the domestic pharmaceutical sector. The poor or inadequate quality of pharmaceutical base materials in the country has led to the dependence of local drug manufacturers on imported materials. Almost $90 \%$ of Saudi Arabian firms' raw material needs are satisfied via imports from France, Germany, Switzerland, Belgium, and the UK. This condition increases the expense of their activities and decreases profit margins. $R \& D$ operations are restrained by the absence of government support and skilled personnel, which, along with improved infrastructure, are needed to ensure the company manufactures more of its own products [17].

The potential success of the pharmaceutical sector does not face any imminent threat, although the lack of native R\&D in this area limits the ability to manufacture new drugs locally. The three main national organizations in the pharmaceutical industry are Saudi Pharmaceutical Industries and Medical Appliances Corporation (SPIMACO), Tabuk Pharmaceuticals Company, and Jamjoom Pharmacy. SPIMACO is the nation's most significant pharmaceutical producer and the secondranked drug company in the country. GlaxoSmithKline's (GSK) main facility is based in Qassim Industrial City. It manufactures more than 150 products, such as brand-name drugs for multinational companies, in conjunction with its own forms of prescription and OTC medication. The company's distribution chain is operated by its subsidiary, ARAC Healthcare Company. Its best products include antibiotics, analgesics, anti-rheumatics, vitamins, and cough/cold remedies. SPIMACO deals with approximately $7.24 \%$ of the entire market sales in 2009 and will soon establish a SAR800 million active pharmaceutical ingredient (API) facility. To promote local production, the government offers incentives to multinational subsidiaries and domestic organizations. These incentives include free property leases, interest-free loans, and government subsidies [18].

\section{Biopharmaceutical Companies' Perception of the Saudi Market}

The major biopharmaceutical players think highly of the Saudi market, as evidenced by the competitive existence of these companies in the Saudi market. One of these companies is Aurobindo, which has more than 20 manufacturing facilities with several partnerships in India, Europe, the USA, and Brazil. The company started investing in Saudi Arabia by 
producing medicines to treat chronic diseases, such as diabetes, heart disease, and hypertension. According to the Director of Aurobindo Pharma, "The decision to base our company's regional operations in Saudi Arabia came in response to the rising demand for our products in the 'Arabian"'. He adds, "Marking our entry into the Saudi market, the new factory in the Industrial Valley will be a major turning point for our company." This valley hosts more than 100 companies and can serve 250 million consumers in the Arab world and East Africa [19].

Another prominent company is Pfizer, which is a global pharmaceutical giant with a unique position in the market, offering various biological products, such as vaccines, and has a longstanding relationship with Saudi Arabia since 1960. Pfizer offers various pharmaceutical services and products covering treatment areas, including oncology, cardiovascular disease, pain, pediatric vaccinations, anti-fungal and antibacterial products, anesthesia, and critical care to patients in Saudi Arabia. Dr. Alaa Abd El Ghany Gamal, Pfizer's country manager, has stated that Pfizer has a diverse portfolio and is one of the premier biopharmaceutical companies globally and in Saudi Arabia. He added that the Saudi government offered an attractive proposition by providing the appropriate supporting infrastructure for expanding their presence and adding manufacturing facilities in the country, the alignment of Pfizer's goals with the country's objectives, combined with the impetus of Vision 2030.

He commented on the Saudi market and said that the Kingdom has stable market dynamics of a pharmaceutical investment with greatly improved SFDA by accelerating the registration process, allowing the products to enter the market faster, and facilitating the bridging process for products with prior FDA approval in the USA or European Union for 60 or 30 working days, respectively [20].

Many European, US, and Indian companies already have established production facilities, especially the King Abdullah Economic Industrial Valley, which produces a full range of products, including antibiotics, diabetic treatments, cardiovascular drugs, and anticoagulants. Opportunities abound for additional manufacturers to establish a presence in the Kingdom, especially in vaccines, APIs, injectables, and biologics [21].

For the first time in the history of the Kingdom of Saudi Arabia, a collaboration among biopharmaceutical industry, academics, and research has been formed to achieve Saudi Vision 2030. The National Industrial Clusters Development Program (NICDP) hosted the signing of mutual memorandums of understanding to localize the vaccine manufacturing industry in the Kingdom and improve academic research and development in line with the latest state-of-the-art technologies and innovation in the biotechnology industry.

The Saudi Vaccine and Biomanufacturing Center hosted a signing ceremony on March 24 in Boston, USA, in front of HRH Crown Prince Mohammed Bin Salman. This center aims to improve the transition into a knowledge-based economy governed by the Saudi Vision 2030. The center aims to facilitate the translation of biological research discoveries into commercial products, which will affect public health. The center also adopts the latest manufacturing technologies for the good manufacturing practice (GMP) of protein and cellbased vaccines with level 2 biosafety capabilities.

Samsung Engineering has been operating in Saudi Arabia since 1999. It is a well-known firm that has executed 32 projects worth about 15 billion dollars worldwide and built the largest biomanufacturing facilities in Korea. SaudiVax wants to make Saudi Arabia self-sufficient in terms of vaccine and biopharmaceutical manufacturing and sales, producing finished dosage formulations (sterile small injectable), active biological ingredients of biopharmaceutical products, and vaccines of importance to our territories [21].

In October 22,019, Saudi Arabian Investment Authority signed a memorandum of understanding with Korea's GL Rapha Co. involving \$320 million for the production of 30 biological drugs in Saudi Arabia. In addition, five other innovative products will be manufactured over the next 5 years, covering all manufacturing stages of biological medicines, including manufacturing raw materials [22].

\section{Previous Studies}

Studies on biopharmaceutics in Saudi Arabia are lacking. The author aims to bridge this gap by analyzing the situation of biopharmaceutics to reveal the strengths and weaknesses, and the results may help in the development of this innovative industry.

A previous study [10] analyzed 130 students enrolled in postgraduate programs in pharmacology to explore their intentions on the pharmaceutical sector and their career paths in this area after graduation. Students who were enrolled in their final year of a pharmacy course at King Saud University in Riyadh participated in the survey.

The findings of the survey revealed that more than $50 \%$ of the students believed that an inadequate amount of information was provided regarding the facilities available to establish pharmaceutical factories. Only $11 \%$ viewed the industrial pharmacy as significant. Regarding the students' projected career paths following graduation, $8 \%$ indicated that they would be involved in the industry. The most prominent reason was the lack of a proper link between the industry and the study of pharmacy in the country. Most of the students $(83.6 \%)$ claimed that they did not receive any training in the pharmaceutical industry, while the others asserted that they possess the knowledge and competencies required to operate in the pharmaceutical sector following graduation. The study indicated that pharmacy students in Saudi Arabia are not qualified to pursue a career in the pharmaceutical industry in the 
country. Several participants $(29.1 \%)$ claimed that they are unwilling to pursue a career in the pharmaceutical industry due to the absence of a connection between universities and the pharmaceutical industry. Exactly $52.1 \%$ stated that they are unfamiliar with the facilities offered by the government to establish pharmaceutical factories. The median amount of companies of which the students were aware was as low as 2 (Riyadh Pharma and SPIMACO).

Pharmacovigilance problems in the pharmaceutical field include the absence of drug manufacturers in Saudi Arabia. The local pharmaceutical manufacturers in the country are few, which represents a significant barrier to the development of pharmaceutical industries [23].

Several studies sought to determine the percentage of pharmacists operating in the industrial field [24]. In the UK, among 65,000 employees from various educational environments, only 2000 are both qualified and working within the pharmaceutical industries. Notably, this number is only 3.5\% of the total industrial workforce. A survey administered by a pharmaceutical organization in the USA illustrated that pharmacists account for $6.8 \%$ of the country's workforce, although they play an essential role in the company. A decrease in the number of pharmacists studying in the industrial field was also found. In Europe, 37,308 pharmacists operate in the industrial field (across 28 countries) out of 603,866 industrial workers (in 23 countries).

The Pharmacy Education in Europe study indicated that a considerable amount $(37,308)$ of European pharmacists $(6 \%$ of the entire workforce) operate in the industry. This figure is similar to the global statistic of $10 \%$ provided by the International Pharmaceutical Federation.

\section{Aims and Objectives}

This paper aimed to identify whether the companies are manufacturing biopharmaceuticals in Saudi Arabia and to determine the causes of the lack of biopharmaceutical manufacturing in Saudi Arabia. Moreover, it aimed to determine whether the company has biopharmaceutical manufacturing facilities that are suitable for the manufacture of biopharmaceuticals but does not possess suitable employees. The study sought to understand the current situation and the views of pharmaceutical-related industries regarding biopharmaceutical development in Saudi Arabia. Accordingly, we employed a survey involving pharmaceutical companies and an interview with several people having different functions and disciplines at the SFDA. Subsequently, we analyzed the results to evaluate the biopharmaceutical industry in Saudi Arabia and its future evolution. On the basis of such aims and objectives, the study sought to answer the following questions:
1. What is the current situation of the biopharmaceutical industry in Saudi Arabia?

2. Is there a lack of biopharmaceutical manufacturing capability in Saudi Arabia? If yes, why?

\section{Methods}

This descriptive study utilized a combination of quantitative and qualitative methods, appropriating the value of both methods' worldviews to develop a deep understanding of the phenomenon of interest. The combination of these methods can help capitalize on the respective strengths of each approach [25]. The study aimed to provide a deep description of the situation of biopharmaceutics from the perspective of the companies in the field of biopharmaceutics and SFDA. The combination of quantitative and qualitative methods involved corroborating findings and producing complete and accurate data [26].

\section{Sample of the Study}

To ensure the representativeness of the sample, the author targeted 18 of 21 Saudi pharmaceutical companies that have received licensing for manufacturing from the SFDA to diagnose the situation of manufacturing in the field of biopharmaceuticals. The targeted respondents were managers or leaders responsible for the development of the company's products, or those who are most familiar with the field of pharmaceuticals. Besides, three officials in the SFDA were interviewed to obtain a clear image of the situation of biopharmaceutics in Saudi Arabia. A total of 25 responses were retrieved from these 18 companies. Three leaders in the SFDA were interviewed as a supplement to the survey.

\section{Instrumentation}

The study employed a questionnaire and an interview to collect the required data. The questionnaire was designed via SurveyMonkey program and sent to 18 pharmaceutical plants, which were pharmaceutical facilities licensed by the SFDA in Saudi Arabia. The questionnaire was developed by reviewing the available content in the ISPE Baseline ${ }^{\circledR}$ Guide: Biopharmaceutical Manufacturing Facilities (Second Edition). ISPE applies to new facilities for the development and manufacture of biopharmaceutical drug substances (or APIs) that should be found in biopharmaceutical plants. The interview that targeted SFDA principals was utilized as a supplement to the survey to obtain sufficient data and a clear image of the situation of biopharmaceutical manufacturing in Saudi Arabia. 
Table 1 Questionnaire design

1. General and plant information

2. Regulatory agencies (critical quality attributes and critical process parameters)

3. Risk management (Pharmaceutical cGMPs in the 21st century - a risk based approach)

4. Process closure (aseptic bioprocessing in closed aseptic systems, background information on biological risks, quality control strategies, and knowledge of stainless-steel bioreactors)

5. Operations

6. CGMP layout approaches

7. Architectural factors

8. Mechanical matters

9. R\&D departments

10. Manufacture of biopharmaceutical drugs

\section{Questionnaire Design}

To ensure the content and construct validity of the questionnaire, the author followed several adequate procedures, which will be sketched below briefly.

\section{Questionnaire}

In the questionnaire, the author followed many procedures to ensure the representativeness of the questionnaire for the topic of investigation. The answers allowed for the questions were "Yes," "No," and "I don't know." These questions highlighted key updates to the guidance pertaining to the ISPE Baseline ${ }^{\circledR}$ Guide. Accordingly, the questionnaire was designed to include the dimensions summarized in Table 1.

\section{Reliability of the Questionnaire}

In terms of the reliability of the questionnaire, all questions have reasonable coefficients and were within the range of
0.47-0.66. Cronbach's alpha coefficient for all the survey items was 0.7 , indicating reasonable reliability.

\section{Interview}

Interviews are a popular tool for gathering information for qualitative research, because they grant opportunities for the researcher to collect meaningful information [27]. The interview targeted three people with different functions and disciplines at the SFDA. The questions were self-prepared to ascertain the industry views of biopharmaceutical development. The interview was sent by email, because this method is preferred by the people at the SFDA. The questions were clear and straightforward, and a summary of the discussion was prepared and kept for analysis. The answers from the SFDA are important for approving the answers of companies about manufacturing biopharmaceuticals and the problems that companies face in relation to biopharmaceuticals and the future of biopharmaceutical production in Saudi Arabia. The interview included Saudi Arabia plans for biopharmaceutical development and the potential for biopharmaceutical manufacturing from the perspective of public health and the

Table 2 Regulatory agencies that the companies follow

\begin{tabular}{lll}
\hline & Frequency & Percent \\
\hline US Food and Drug Administration (FDA) & 16 & 64.00 \\
European Medicines Agency (EMA) & 11 & 44.00 \\
European Commission (EC), Public Health & 15 & 28.00 \\
World Health Organization (WHO) & 12 & 60.00 \\
International Conference on Harmonization (ICH) & 12 & 48.00 \\
Pharmaceutical Inspection Convention and Pharmaceutical Inspection & 1 & 32 \\
$\quad$ Co-operation Scheme (jointly referred to PICIS) & 0 & 4.00 \\
International Federation of Biosafety Association (IFBA) & 1 & 0.00 \\
Japan Pharmaceuticals and Medical Devices Agency (PDMA) & 1 \\
Association of Southeast Asian Nations (ASEAN) & & 4 \\
\hline
\end{tabular}


Table 3 Regulatory issues

\begin{tabular}{|c|c|c|c|}
\hline Questions & Yes & No & I do not know \\
\hline $\begin{array}{l}\text { Are critical quality attributes and critical process parameters (CPPs and CQAs) of } \\
\text { both current and projected future products considered in your facility's design? }\end{array}$ & $\begin{array}{l}88.00 \% \\
22\end{array}$ & $\begin{array}{l}4 \% \\
1\end{array}$ & $\begin{array}{l}8 \% \\
2\end{array}$ \\
\hline $\begin{array}{l}\text { Does the company have an understanding of biopharmaceutical production, } \\
\text { particularly for bulk biopharmaceutical drug substance processes? }\end{array}$ & $\begin{array}{l}44 \% \\
11\end{array}$ & $\begin{array}{l}44 \% \\
11\end{array}$ & $\begin{array}{l}12 \% \\
3\end{array}$ \\
\hline $\begin{array}{l}\text { Does your company provide a closed processing facility, such as multiple closed } \\
\text { bioreactors, upstream operations, and downstream processing, in your site? }\end{array}$ & $\begin{array}{l}16 \% \\
4\end{array}$ & $\begin{array}{l}68 \% \\
17\end{array}$ & $\begin{array}{l}16 \% \\
4\end{array}$ \\
\hline
\end{tabular}

medical economy. The questions included in the interview focused on the future of biopharmaceutical drugs in the country.

\section{Ethical Issues}

The confidentiality of the information was ensured through anonymity and its sole use for the purpose of this project. The survey envelopes contained the first letter of the confidentiality of the participant's responses, indicating that their responses would remain strictly anonymous and confidential. The participants' responses were reported and analyzed in a manner that they cannot be linked or traced to any individual.

\section{Results}

This section presents the results of the survey and interview. The results were structured based on the data retrieved by the instruments. The results of the questionnaire were structured in accordance with the main sections. The interview responses were analyzed qualitatively.

\section{Questionnaire}

The results of the questionnaire were structured based on the main elements of the questionnaire (regulatory agencies, risk management, process closure, operations, CGMP layout approaches, architecture, mechanical, $\mathrm{R} \& \mathrm{D}$, and manufacture).

\section{Regulatory Issues}

This section consists of four questions. The first question concerns the regulatory agencies with which the company complies. The companies' responses revealed that they complied with the following agencies: US FDA, European Medicines, European Commission, World Health Organization, International Conference on Harmonization, Pharmaceutical Inspection Convention, International Federation Biosafety Association, Japan Pharmaceutical and Medical Diverse Agency, and Association of Southeast Asian Nations (Table 2).

The second question revealed that $88 \%$ of the facility's design of the companies consider critical quality attributes and process parameters (CPPs and CQAs) of both current and projected future products, and the other responses were distributed between No $(4 \%)$ and I don't know $(8 \%)$. The responses to the third question revealed that $44 \%$ agreed, $44 \%$ disagreed, and $12 \%$ did not know whether their companies understand biopharmaceutical production (bulk biopharmaceutical drug substance processes). The responses to the fourth question revealed that $16 \%$ agreed and $68 \%$ disagreed that the companies provide a closed processing facility, such as multiple closed bioreactors, upstream operations, and downstream processing, whereas $16 \%$ were not aware of any (Table 3).

\section{Risk Management}

This section consists of four questions that aim to explore how the targeted companies manage risks. The responses to the first

Table 4 Management risk

\begin{tabular}{|c|c|c|c|}
\hline Question & Yes & No & Do not know \\
\hline \multirow{2}{*}{$\begin{array}{l}\text { 1. Does your company provide a method for evaluating the risks of } \\
\text { cross-contamination and contamination from the environment during } \\
\text { the manufacturing of bulk drug substances, specifically during bioprocessing? }\end{array}$} & $64 \%$ & $28 \%$ & $8 \%$ \\
\hline & 16 & 7 & 2 \\
\hline \multirow{2}{*}{$\begin{array}{l}\text { 2. Does your company have knowledge of the use of risk management in the } \\
\text { biopharmaceutical industry? }\end{array}$} & $52 \%$ & $32 \%$ & $16 \%$ \\
\hline & 13 & 8 & 4 \\
\hline \multirow{2}{*}{$\begin{array}{l}\text { 3. Are the risk assessments in your company incorporated into corrective } \\
\text { action and preventative action (CAPA) programs? }\end{array}$} & $92 \%$ & 0 & $8 \%$ \\
\hline & 23 & 0 & 2 \\
\hline \multirow{2}{*}{$\begin{array}{l}\text { 4. Do you have methods and approaches used for assessing risks in } \\
\text { biopharmaceutical manufacturing in your company? }\end{array}$} & $40 \%$ & $56 \%$ & $4 \%$ \\
\hline & 10 & 14 & 1 \\
\hline
\end{tabular}


Table 5 Process closure

\begin{tabular}{|c|c|c|c|}
\hline Questions & Yes & No & I do not know \\
\hline $\begin{array}{l}\text { Does your company have information about the importance of performing } \\
\text { aseptic bioprocessing in a closed aseptic system? }\end{array}$ & $\begin{array}{l}56 \% \\
14\end{array}$ & $\begin{array}{l}28 \% \\
7\end{array}$ & $\begin{array}{l}\% 16 \\
4\end{array}$ \\
\hline $\begin{array}{l}\text { Does your company have background information regarding the biological } \\
\text { risks to a biopharmaceutical process and the products of particulates and } \\
\text { bioburden contamination (such as bacteria, yeasts, or mold contamination) } \\
\text { in the environment? }\end{array}$ & $\begin{array}{l}68 \% \\
17\end{array}$ & $\begin{array}{l}24 \% \\
6\end{array}$ & $\begin{array}{l}8 \% \\
2\end{array}$ \\
\hline $\begin{array}{l}\text { Does your company provide quality control strategies and appropriate storage } \\
\text { conditions to mitigate and monitor the risk of contamination from raw materials? }\end{array}$ & $\begin{array}{l}96 \% \\
24\end{array}$ & $\begin{array}{l}0 \\
1\end{array}$ & $\begin{array}{l}4 \% \\
1\end{array}$ \\
\hline Does your company have an effective cleaning and sanitation program? & $\begin{array}{l}92 \% \\
23\end{array}$ & $\begin{array}{l}4 \% \\
1\end{array}$ & $\begin{array}{l}4 \% \\
1\end{array}$ \\
\hline $\begin{array}{l}\text { Does your company provide different approaches and layers of protection to mitigate } \\
\text { the risk of contamination from the environment to a bioprocess unit operation? }\end{array}$ & $\begin{array}{l}68 \% \\
17\end{array}$ & $\begin{array}{l}20 \% \\
5\end{array}$ & $\begin{array}{l}12 \% \\
3\end{array}$ \\
\hline $\begin{array}{l}\text { Does your company use risk assessments to demonstrate that a process has been } \\
\text { successfully isolated from the surrounding environment and that the environment } \\
\text { no longer represents a critical aspect of this process? }\end{array}$ & $\begin{array}{l}72 \\
18\end{array}$ & $\begin{array}{l}20 \% \\
5\end{array}$ & $\begin{array}{l}8 \% \\
2\end{array}$ \\
\hline $\begin{array}{l}\text { Does your company have knowledge of stainless-steel bioreactors used in a cell } \\
\text { culture operation in the biopharmaceutical field? }\end{array}$ & $\begin{array}{l}32 \% \\
8\end{array}$ & $\begin{array}{l}60 \% \\
15\end{array}$ & $\begin{array}{l}8 \% \\
2\end{array}$ \\
\hline
\end{tabular}

question revealed that $64 \%, 28 \%$, and $8 \%$ agreed, disagreed, and did not know that their companies provide a method for evaluating the risks of cross-contamination and contamination from the environment during the manufacturing of bulk drug substances, respectively. The second question revealed that $52 \%, 32 \%$, and $16 \%$ agreed, disagreed, and did not know that their company has the knowledge about the use of risk management in the biopharmaceutical industry. The responses to the third question revealed that $92 \%$ of the companies incorporated risk assessment into corrective and preventative action programs. The fourth question's responses revealed that $40 \%$, $56 \%$, and $4 \%$ agreed, disagreed, and did not know that their companies employ methods and approaches for assessing risks in biopharmaceutical manufacturing (Table 4).

\section{Process Closure}

The process closure consists of seven items. The responses to the first question revealed that $68 \%, 28 \%$, and $16 \%$ agreed, disagreed, and did not know that their companies have information about the importance of performing aseptic bioprocessing, respectively. For the companies' background of biological risks, $68 \%, 24 \%$, and $8 \%$ agreed, disagreed, and did not know about their companies' background of biological risks, respectively. Most of the participants (96\%) agreed that their companies provided quality control strategies and appropriate storage conditions to mitigate and monitor the risk of contamination from raw materials. Similarly, $92 \%$ agreed that their companies have an effective cleaning and sanitization program. Exactly $86 \%, 20 \%$, and $12 \%$ agreed, disagreed, and did not know that their companies provide different approaches and layers of protection, respectively. Approximately $72 \%, 20 \%$, and $8 \%$ agreed, disagreed, and did not know that their companies use risk assessment, respectively. The last section revealed that 32\%, 60\%, and $8 \%$ agreed, disagreed, and did not know that their companies have knowledge about stainless-steel bioreactors (Table 5).

\section{Operations}

Regarding operations, $48 \%$ and $52 \%$ agreed and disagreed that their companies consider the operational aspects of a biopharmaceutical facility and the effects of facility and equipment design decisions on manufacturing operations, respectively. Exactly $28 \%, 60 \%$, and $12 \%$ agreed, disagreed, and did know that they dealt with a single-use system in their site, respectively (Table 6).

Table 6 Operations

\begin{tabular}{llll}
\hline Questions & Yes & No & Do not know \\
\hline Does your company consider the operational aspects of a biopharmaceutical & $48 \%$ & $52 \%$ & $0 \%$ \\
$\quad$ facility and the effects of facility and equipment design decisions on & 12 & 13 & 0 \\
$\quad$ manufacturing operations? & 28 & 60 & $12 \%$ \\
Have you ever dealt with a single-use system in your site? & 7 & 15 \\
\hline
\end{tabular}


Table 7 CGMP layout approaches

\begin{tabular}{|c|c|c|c|}
\hline Questions & Yes & No & Do not know \\
\hline $\begin{array}{l}\text { Is the facility layout in your manufacturing plant focused on } \\
\text { protecting the product? }\end{array}$ & $\begin{array}{l}88 \% \\
22\end{array}$ & $\begin{array}{l}8 \% \\
2\end{array}$ & $\begin{array}{l}4 \% \\
1\end{array}$ \\
\hline $\begin{array}{l}\text { Is your company aware that production scale and process technology } \\
\text { improvements can significantly affect facility layout? }\end{array}$ & $\begin{array}{l}84 \% \\
21\end{array}$ & $\begin{array}{l}0 \\
0\end{array}$ & $\begin{array}{l}16 \% \\
4\end{array}$ \\
\hline $\begin{array}{l}\text { Does your company prevent product contamination by segregating } \\
\text { sources of product contamination from the product? }\end{array}$ & $\begin{array}{l}88 \% \\
22\end{array}$ & $\begin{array}{l}8 \% \\
2\end{array}$ & $\begin{array}{l}4 \% \\
1\end{array}$ \\
\hline $\begin{array}{l}\text { Does your company have environmental protection of an exposed } \\
\text { product, such as a classified clean room environment? }\end{array}$ & $\begin{array}{l}92 \% \\
23\end{array}$ & $\begin{array}{l}4 \% \\
1\end{array}$ & $\begin{array}{l}4 \% \\
1\end{array}$ \\
\hline $\begin{array}{l}\text { Does your company provide facility and process flows that are designated } \\
\text { paths of travel for personnel, materials, product, equipment cleaning, and solid waste? }\end{array}$ & $\begin{array}{l}96 \% \\
24\end{array}$ & $\begin{array}{l}0 \\
0\end{array}$ & $\begin{array}{l}4 \% \\
1\end{array}$ \\
\hline
\end{tabular}

\section{CGMP Layout Approaches}

This section includes five questions. The responses to the first question revealed that $88 \%, 8 \%$, and $4 \%$ agreed, disagreed, and did not know that the facility layout in their manufacturing plant focused on protecting the product, respectively. Exactly $84 \%$ and $16 \%$ agreed and disagreed that their companies were aware that production scale and process technology improvements can significantly affect facility layout, respectively. The responses to the third question revealed that $88 \%, 8 \%$ and $4 \%$ agreed, disagreed, and did not know that their companies prevent product contamination by segregating sources of product contamination from the product, respectively. Most of the respondents (92\% and 96\%) agreed with the last two questions (Table 7).

\section{Architecture}

Regarding architecture, 48\%, 40\%, and $12 \%$ agreed, disagreed, and did not know that the facility design of biopharmaceuticals and vaccines have features of concern for their company, respectively (Table 8).

\section{Mechanical Matters}

This section includes three questions. Exactly 44\%, 32\%, and $24 \%$ agreed, disagreed, and did not know that their companies evaluate each step in the manufacture of a biopharmaceutical drug substance for risk factors, respectively. Exactly $84 \%$, $12 \%$, and $4 \%$ agreed, disagreed, and did not know that their companies provide an HVAC system that enhances or provides appropriate environmental parameters. Finally, $60 \%, 24 \%$, and $16 \%$ agreed, disagreed, and did not know that their companies follow the classification of critical environments in biotechnology and vaccine facilities on the basis of airborne particulate concentration, as outlined in ISO, respectively (Table 9).

Table 10 shows the classification that the companies follow in compliance with environmental control requirements.

\section{R\&D}

Regarding R\&D, $80 \%$ and $20 \%$ agreed that they perform R\&D in their companies, respectively. Approximately $20 \%$, $60 \%$, and $20 \%$ agreed, disagreed, and did not know that their companies are interested in biopharmaceutical research, respectively. Exactly $12 \%, 68 \%$, and $12 \%$ agreed, disagreed, and did not know that they have domestic researchers for recruitment in biopharmaceutical research, respectively (Table 11).

\section{Manufacture}

All participants disagreed that their companies manufactured biopharmaceutical drugs. Exactly 28\%, 36\%, and 36\% agreed, disagreed, and did not know that they seek to manufacture biopharmaceutical drugs, respectively. About $76 \%$ and $24 \%$ disagreed and did not know that they have biopharmaceutical drugs under development, respectively. Approximately $10.53 \%, 78.95 \%$, and $10.53 \%$ agreed, disagreed, and did not agree with the availability of a biological safety program in their work area, respectively. A total of

Table 8 Architecture

\begin{tabular}{llll}
\hline Questions & Yes & No & I do not know \\
\hline $\begin{array}{l}\text { Do you believe that the facility design of biopharmaceuticals and } \\
\text { vaccines have features of concern for your company? }\end{array}$ & $48 \%$ & $40 \%$ & $12 \%$ \\
& 12 & 10 & 3 \\
\hline
\end{tabular}


Table 9 Mechanical matters

\begin{tabular}{|c|c|c|c|}
\hline Questions & Yes & No & I do not know \\
\hline $\begin{array}{l}\text { If the company manufactures biopharmaceutical drugs, does it evaluate } \\
\text { each step in the manufacture of a biopharmaceutical drug substance } \\
\text { for risk factors? }\end{array}$ & $44 \%$ & $32 \%$ & $24 \%$ \\
\hline $\begin{array}{l}\text { Does your company provide an HVAC system that enhances or provides } \\
\text { appropriate environmental parameters? }\end{array}$ & $84 \%$ & $12 \%$ & $4 \%$ \\
\hline $\begin{array}{l}\text { Does your company follow the classification of critical environments in } \\
\text { biotechnology and vaccine facilities on the basis of airborne particulate } \\
\text { concentration, as outlined in ISO? }\end{array}$ & $60 \%$ & $24 \%$ & $16 \%$ \\
\hline
\end{tabular}

$88 \%$ and $12 \%$ disagreed and did not know that they have biosafety containment for recombinant DNA molecules. Approximately $33.33 \%, 16.67 \%$, and $50 \%$ agreed, disagreed, and did not know that biosafety containment is a barrier to the manufacture of biopharmaceutical drugs, respectively. Exactly $24 \%, 28 \%$, and $45 \%$ agreed, disagreed, and did not know that they will develop biopharmaceuticals in the future, respectively. Moreover, 44\%, 16\%, and 40\% agreed, disagreed, and did not know that clinical trials are the main problem for biopharmaceutical manufacturers, respectively (Table 12).

The main problems that the companies face in developing innovation dugs are listed in Table 13.

\section{Interview}

Interviews were conducted as a supplement to the survey. The interviews targeted three officials in the SFDA. The interview was structured in the form of open questions (Table 14).

\section{Discussion}

Results revealed a severe lack of biopharmaceutical production in Saudi Arabia, as indicated by the results of the questionnaire for companies. About $100 \%$ of companies do not manufacture biopharmaceuticals, as supported by the SFDA officials' responses in the interview. According to the SFDA, only one company is engaged in secondary packaging of some vaccines. GSK's main facility is based in Qassim Industrial City. It manufactures more than 150 products, such as brandname drugs for multinational companies, in conjunction with its own forms of prescription and OTC medication [17]. The company seeks to produce more than four biopharmaceutical drugs, including HIV drugs, over the next 5 years.

Three people of different functions and disciplines at the SFDA stated that two companies have applied for biopharmaceutical manufacturing, but operations have not begun. These companies aim to manufacture vaccines and insulin. The SFDA interviewees did not clarify the types of vaccines that the companies seek to manufacture.

The findings revealed the willingness of companies to manufacture biopharmaceuticals. As mentioned in the literature review, Saudi Arabia is the most significant pharmaceutical market in the Middle East region and has a rapidly increasing economy. Its GDP is included in the top 30 worldwide. Thus, it is an encouraging market for biopharmaceutical firms [15]. However, biopharmaceutical production in the country is lacking.

Notably, the lack of reliability affected a portion of the answers provided for this research. Inaccurate responses ("I don't know") meant that the intended meaning was unclear on certain occasions. This scenario may be due to the shortcomings in the respondent's knowledge of biopharmaceutical manufacturing. Conversely, it possibly resulted from the misinterpretation of the nature of the question asked.

Considering the experience of or the perception of the risk of biopharmaceutical manufacturing-related problems in

Table 10 Classification that the companies follow

\begin{tabular}{lll}
\hline & Classification & Percent \\
\hline $\begin{array}{l}\text { What is the classification that your company follows regarding environmental } \\
\text { control requirements? (Please tick those which apply.) }\end{array}$ & ISO 14644-3 & 76.19 \\
& EU and PIC/S & 66.67 \\
16 & ISPE grade & 14.29 \\
3 & PIC/S Grad & 9.52 \\
\hline
\end{tabular}


Table $11 \quad$ R\&D

\begin{tabular}{|c|c|c|c|}
\hline Questions & Yes & No & I do not know \\
\hline Do you have an R\&D department in your company? & $\begin{array}{l}80 \% \\
20\end{array}$ & $\begin{array}{l}20 \% \\
5\end{array}$ & $0 \%$ \\
\hline If so, is the R\&D in your company interested in biopharmaceutical research? & $\begin{array}{l}20 \% \\
5\end{array}$ & $\begin{array}{l}60 \% \\
15\end{array}$ & $\begin{array}{l}20 \% \\
5\end{array}$ \\
\hline Do you have domestic researchers for recruitment in biopharmaceutical research? & $\begin{array}{l}12 \% \\
3\end{array}$ & $\begin{array}{l}68 \% \\
17\end{array}$ & $\begin{array}{l}12 \% \\
3\end{array}$ \\
\hline
\end{tabular}

clinical trials, the SFDA interviewees asserted, "No, there are requirements (GMP certificate and certificate of analysis) to minimize biopharmaceutical manufacturing-related problems." Moreover, they claimed that the reason underlying the lack of biological medicine manufacture in Saudi Arabia was the difficulty of clinical trials and financial problems.

About $76 \%$ of the problems that many companies face in developing innovative biopharmaceutical drugs were attributed to design facilities. Financial problems and research problems were the second most common problems related to manufacturing biopharmaceuticals in Saudi Arabia, accounting for $68 \%$ and $60 \%$, respectively. The ISPE book was set as the reference point for the preparation of the questionnaire in terms of the responses. The most common problem that many companies face in developing innovative drugs (biologicals/ biotech) is the design of the facility. The availability of facilities for the manufacture of biopharmaceuticals is required for the industrialization of biopharmaceuticals in Saudi Arabia.

Poor investment in R\&D is due to the lack of sufficiently skilled personnel, resulting in a dearth of technical knowledge and insufficient infrastructure. Moreover, poor production of pharmaceutical-based materials in the country has led to the dependence of local drug manufacturers on imported materials. Almost $90 \%$ of Saudi Arabian firms' raw material needs are satisfied via imports from France, Germany, Switzerland, Belgium, and the UK [16].

In general, the companies have the essential requirements for manufacturing pharmaceuticals but not in regard to the specific requirements of biopharmaceuticals. For example, only $16 \%$ of companies provide a closed processing facility, such as multiple closed bioreactors, upstream operations, and downstream processing. Closed processing dissociates the process from the facility and isolates the process from neighboring activities effectively to provide safety for products. Some answers are inconsistent. For instance, $16 \%$ answered that the company provides closed processing facilities, such as multiple closed bioreactors, upstream operations, and downstream processing, whereas no company manufactures biopharmaceuticals. In addition, regarding the availability of a biological safety program in the company working area, for the company with biopharmaceutical drugs that are under development, approximately $79 \%$ answered No, and this answer contradicts the answers in part 2 of the survey concerning risk management. This inconsistency is related to indifference or misunderstanding due to the language barrier in relation to some respondents.

Table 12 Manufacture

\begin{tabular}{|c|c|c|c|}
\hline Questions & Yes & No & I do not know \\
\hline Is the company manufacturing biopharmaceutical drugs? & $\begin{array}{l}0 \% \\
0\end{array}$ & $\begin{array}{l}100 \% \\
25\end{array}$ & $\begin{array}{l}0 \% \\
0\end{array}$ \\
\hline Are you seeking to manufacture biopharmaceutical drugs? & $\begin{array}{l}28 \% \\
7\end{array}$ & $\begin{array}{l}36 \% \\
9\end{array}$ & $\begin{array}{l}36 \% \\
9\end{array}$ \\
\hline Do you have biopharmaceutical drugs under development? & $\begin{array}{l}0 \% \\
0\end{array}$ & $\begin{array}{l}76 \% \\
19\end{array}$ & $\begin{array}{l}24 \% \\
6\end{array}$ \\
\hline If so, do you have a biological safety program in your working area? & $\begin{array}{l}10.53 \% \\
2\end{array}$ & $\begin{array}{l}78.95 \% \\
15\end{array}$ & $\begin{array}{l}10.53 \% \\
2\end{array}$ \\
\hline Do you have biosafety containment for recombinant DNA molecules? & $\begin{array}{l}0 \% \\
0\end{array}$ & $\begin{array}{l}88 \% \\
22\end{array}$ & $\begin{array}{l}12 \% \\
3\end{array}$ \\
\hline $\begin{array}{l}\text { If not, do you think biosafety containment is a barrier to the } \\
\text { manufacture of biopharmaceutical drugs? }\end{array}$ & $\begin{array}{l}33.33 \% \\
8\end{array}$ & $\begin{array}{l}16.67 \% \\
4\end{array}$ & $\begin{array}{l}50 \% \\
12\end{array}$ \\
\hline Do you plan to develop biopharmaceuticals in the future? & $\begin{array}{l}24 \% \\
6\end{array}$ & $\begin{array}{l}28 \% \\
7\end{array}$ & $\begin{array}{l}48 \% \\
12\end{array}$ \\
\hline $\begin{array}{l}\text { Do you believe that clinical trials are the main problem for } \\
\text { biopharmaceutical manufacturers? }\end{array}$ & $\begin{array}{l}44 \% \\
11\end{array}$ & $\begin{array}{l}16 \% \\
4\end{array}$ & $\begin{array}{l}40 \% \\
10\end{array}$ \\
\hline
\end{tabular}


Table 13 Classification of problems

\begin{tabular}{lllr}
\hline Questions & Problems & Frequency & Percent \\
\hline $\begin{array}{c}\text { What kinds of financial } \\
\text { or other problems }\end{array}$ & Financial problems & 17 & 68.00 \\
may companies face & Design facility problems & 19 & 76.00 \\
$\begin{array}{l}\text { in the development of } \\
\text { innovative drugs }\end{array}$ & Equipment problems & 12 & 48.00 \\
(biologicals/biotech)? & Research problems & 15 & 60.00 \\
& $\begin{array}{l}\text { Scientific problems } \\
\text { Clinical trial problems }\end{array}$ & 14 & 36.00 \\
& $\begin{array}{l}\text { Reasons for your } \\
\text { answers above, and if }\end{array}$ & 1 & 56.00 \\
& $\begin{array}{l}\text { you have other } \\
\text { problems (please }\end{array}$ & \\
& specify): & \\
\hline
\end{tabular}

About $60 \%$ of companies are not interested in biopharmaceutical research, and $68 \%$ do not have domestic researchers for recruitment in biopharmaceuticals. Although the lack of native $R \& D$ in relation to the area is a serious hindrance to the ability to manufacture new drugs locally, the potential success of the pharmaceutical sector faces no imminent threats [17]. By contrast, the USA possesses the most sophisticated biopharmaceutical industry in terms of $R \& D$ and a wide array of products and market scale. Most biopharmaceuticals are licensed initially in the USA and later in other areas [3].

In China, the development of the biopharmaceutical industry is achieved via an approach that extends across the whole nation, involving R\&D policy, which is guided by the government and energetic participation facilitated by research organizations and performed mainly by manufacturers [3]. Progress in the R\&D of the USA and China indicates the importance of research and development in the biopharmaceutical field, thereby supporting that research will enhance the biopharmaceutical industry of Saudi Arabia.

For the regulatory procedure (marketing authorization procedure) that biopharmaceutical companies should follow, the SFDA interviewees referred to the latest version 5.0 of the guidance titled "Regulatory framework for drug approvals." The biological products that are intended for the Saudi Arabia market are subject to a marketing authorization assessment. Several guidelines have been devised in relation to biological products, and these guidelines are categorized based on the purpose of their application, including new registration, variation, and renewal [13].

\section{Conclusion}

This research aimed to evaluate the situation of the biopharmaceutical industry in Saudi Arabia in terms of the revolution in biopharmaceuticals worldwide. Accordingly, the research methodology involved a combination of quantitative and

Table 14 Interview

\begin{tabular}{|c|c|c|}
\hline No. & Questions & Answers \\
\hline 1 & $\begin{array}{l}\text { How many companies are manufacturing } \\
\text { biopharmaceutical drugs? }\end{array}$ & $\begin{array}{l}\text { Two companies are manufacturing biopharmaceutical drugs, } \\
\text { but they have not commenced yet. }\end{array}$ \\
\hline 2 & $\begin{array}{l}\text { If there is no manufacture of biopharmaceutical } \\
\text { drugs, what causes the lack of biological } \\
\text { medicine manufacture in Saudi Arabia? }\end{array}$ & $\begin{array}{l}\text { Financial problems } \\
\text { Difficulty of clinical trials }\end{array}$ \\
\hline 3 & $\begin{array}{l}\text { In general, what kinds of biopharmaceutical } \\
\text { drugs is the country most interested in? }\end{array}$ & $\begin{array}{l}\text { The SFDA regulates all kinds and subtypes of biological } \\
\text { products, including vaccines, blood and blood components, } \\
\text { allergens, somatic cells, gene therapy, tissues and } \\
\text { recombinant therapeutic proteins, and biosimilar medicines. }\end{array}$ \\
\hline \multirow[t]{5}{*}{4.} & Do you have biopharmaceutical drugs under development? & $\begin{array}{l}\text { No companies have been able to register biopharmaceutical } \\
\text { drugs until now. }\end{array}$ \\
\hline & $\begin{array}{l}\text { What kind of a regulatory procedure (marketing authorization } \\
\text { procedure) } \\
\text { should biopharmaceutical companies follow (i.e., at which } \\
\text { points should the regulatory authorities treat } \\
\text { biopharmaceuticals differently)? }\end{array}$ & $\begin{array}{l}\text { Please refer to the latest version } 5.0 \text { of the guidance } \\
\text { titled "Regulatory framework for drug approvals" } \\
\text { accessed at }<\text { http://old.sfda.gov.sa/en/drug/drug_reg/Pages/drug_reg. } \\
\text { aspx }\end{array}$ \\
\hline & $\begin{array}{l}\text { From which of these countries has Saudi Arabia imported } \\
\text { biopharmaceutical drugs or considered doing so? }\end{array}$ & The USA, Canada, the UK, Japan, and Korea \\
\hline & $\begin{array}{l}\text { Have you experienced, or do you think that a risk of } \\
\text { biopharmaceutical manufacturing-related problems } \\
\text { may occur in clinical trials? }\end{array}$ & $\begin{array}{l}\text { No. Some requirements (GMP certificate and certificate of analysis) } \\
\text { are set to minimize biopharmaceutical manufacturing-related } \\
\text { problems. }\end{array}$ \\
\hline & $\begin{array}{l}\text { Have you experienced, or do you think that problems } \\
\text { may arise in the clinical studies of biopharmaceuticals? }\end{array}$ & $\begin{array}{l}\text { Any clinical trial involves potential risks, and the approval } \\
\text { depends on the benefit-risk assessment. No specific } \\
\text { problems exist for clinical studies of biopharmaceuticals. }\end{array}$ \\
\hline
\end{tabular}


qualitative methods to develop a deep understanding of the phenomenon of interest.

Findings revealed a serious lack of biopharmaceutical manufacture in Saudi Arabia. Facility design is a major challenge for companies, followed by financial and research problems. Most companies aim toward manufacturing biopharmaceuticals in the next few years. The future of the biopharmaceutical field in the country is promising, as revealed by the interview with the SFDA personnel, who clarified that two companies have applied to the SFDA to manufacture insulin and vaccines but operations have not begun. This initiative is promising, although the progress is behind the revolution of biopharmaceuticals worldwide.

\section{Recommendations}

On the basis of the findings, the study recommended that Saudi Arabia should engage in workshops similar to those provided by the National Institute for Bioprocessing Research \& Training (NIBRT) in Ireland. This world-renowned body offers training in relation to the bioprocessing industry, thereby aiding the bioprocessing industry by facilitating a particular learning process within a rail that reflects the latest industrial bioprocessing facilities. The NIBRT also offers important research in significant areas of bioprocessing in partnership with the industry (NIBRT, 2016). This step will provide Saudi Arabia's biopharmaceutical industry employees with the ability to improve and develop the biopharmaceutical industry in Saudi Arabia.

Foreign investment should be encouraged in Saudi Arabia, especially investment from companies with experience in biopharmaceuticals. Accordingly, these experiences will be shared among the pharmaceuticals sector, because of the country's interest in the pharmaceutical industry. Thus, Saudi Arabia is a good location for the companies to explore.

Regarding the survey, most of the participants were not from Saudi Arabia. Few Saudi Arabians are involved in the field of industrial pharmacy. From the author's perspective and on the basis of the literature review, the university curriculum features a significantly poor design in relation to general pharmaceutical industrial practices, especially in the biopharmaceutical industry, which has been clarified and discussed in this research. The disconnect between colleges and the pharmaceutical industry is the main reason for the gap between them. The pharmaceutical industry lacks biopharmaceutical manufacture and pharmacy practice, and this area needs further investigation.

\section{References}

1. Otto R, Santagostino A, and Schrader U. Rapid growth in biopharma: challenges and opportunities. 2014.
2. Horikawa H, Tsubouchi M, Kawakami K. Industry views of biosimilar development in Japan. Health Policy. 2009;91(2):189-94.

3. Gao K, Wang J. The biopharmaceutical industry in China: history and future. Higher Education Press and Springer-Verlag Berlin Heidelberg 2012;6(2), 101-111.

4. Kazuyuki M. OECD/TIP project on biopharmaceutical national innovation systems. Japan: National Report: Japan 2004.

5. $\mathrm{Hu} \mathrm{X}, \mathrm{Ma} \mathrm{Q}$, Zhang S. Biopharmaceuticals in China. Biotechnol J. 2006;1(11):1215-24.

6. Pharmaceutical research and manufacturers of America. 2015.

7. Cramer C, Boothe J, Oishi K. Transgenic plants for therapeutic proteins: linking upstream and downstream strategies. In: Hammond J, McGarvey P, Yusibov V, editors. Plant biotechnology. Current topics in microbiology and immunology, vol. 240. Berlin, Heidelberg: Springer; 2000.

8. Jungbauer A. Continuous downstream processing of biopharmaceuticals. Trends Biotechnol. 2013;31(8):479-92.

9. Xia T, Roper S. Worlds apart? A comparison of the new product development strategies of biopharmaceutical firms in Europe and the USA. Ind Innov. 2009;16(6):593-612.

10. Shan W, Song J. Foreign direct investment and sourcing of technological advantage: evidence from the biotechnology industry. J Int Bus Stud. 1997;28(2):267-84.

11. Bin Saleh G, Rezk N, Laika L, Ali A, El-Metwally A. Pharmacist, the pharmaceutical industry and pharmacy education in Saudi Arabia: a questionnaire-based study. Saudi Pharm J. 2015;23(5): 573-80.

12. Zhou Y. Opportunities in biopharmaceutical outsourcing to China. BioProcess International 2007;16-23.

13. Cockburn I, Slaughter M. The global location of biopharmaceutical knowledge activity: new findings, new questions. In: Stern JL, editor. Innovation Policy and the Economy. Chicago: University of Chicago Press; 2015. p. 129-57.

14. Alsamil A. Regulatory submissions for blood products at Saudi FDA. In: Pharmaceutical Regulatory Affairs. San Francisco: OMICS Group Conferences; 2013.

15. Gardiner RB and Edathodu A. Saudi Arabia: a very attractive biopharmaceutical market. 2014.

16. Issa N, Al-Ammar M, and Mostafa S. Healthcare and Pharmaceutical Industries in Saudi Arabia. International Healthcare Affinity Group of The Business Law and Governance Practice Group. American Health Lawyer Association. 2009.

17. Aljazira. Saudi Pharmaceutical Industries \& Medical Appliances Corporation. Saudi Arabia: Research Department Company Reports.2010.

18. Alahli. Saudi Pharmaceuticals Sector Review. Saudi Arabia: NCB's Economics Department. 2011.

19. Aurobindo Entry to Saudi market building a Pharmaceutical Factory in Industrial valley - KAEC. (2020). Retrieved 13 January 2020, from https://www.ic.gov.sa/en/clusters/ pharmaceutical-biotech/news/aurobindo-entry-to-saudi-marketbuilding-a-pharmaceutical-factory-in-industrial-valley-kaec/.

20. PFizer - Healthcare and Life Sciences. (2020). Retrieved 13 January 2020, from https://investsaudi.sa/en/sectors-opportunities/ healthcare-and-life-sciences/pfizer/.

21. SaudiVax. (2020). Retrieved 13 January 2020, from https://www.ic. gov.sa/en/clusters/pharmaceutical-biotech/success-stories/ saudivax/.

22. Saudi-Korean $\mathrm{MoU}$ to Invest $\$ 320 \mathrm{Mn}$ in Biopharmaceutical Plant. (2020). Retrieved 13 January 2020, from https://aawsat.com/ english/home/article/1929856/saudi-korean-mou-invest-320mnbiopharmaceutical-plant.

23. Shankar P, Jha N, Aljadhey H, Pitts P. A qualitative exploration of the major challenges facing pharmacovigilance in Saudi Arabia. Saudi Med J. 2015;36(11):1369-70. 
24. Atkinson J, Crowley P, De Paepe K, Gennery B, Koster A, Martini $\mathrm{L}$, et al. A European competence framework for industrial pharmacy practice in biotechnology. Pharmacy. 2015;3(3):101-28.

25. Curry L, Nembhard I, Bradley E. Qualitative and mixed methods provide unique contributions to outcomes research. Circulation. 2009;119:1442-52. https://doi.org/10.1161/CIRCULATIONAHA. 107.742775 .

26. Venkatesh V, Brown S, Bala H. (2013). Bridging the qualitativequantitative divide: guidelines for conducting mixed methods research in information systems. MIS Q. 2009;37(1):21-54.
27. Frels R, Onwuegbuzie A. Administering quantitative instruments with qualitative interviews: a mixed research approach. J Couns Dev. 2013;91(2):184-94.

Publisher's Note Springer Nature remains neutral with regard to jurisdictional claims in published maps and institutional affiliations. 